\title{
A dissimilatory sirohaem-sulfite-reductase-type protein from the hyperthermophilic archaeon Pyrobaculum islandicum
}

\author{
Michael Molitor, ${ }^{1}$ Christiane Dahl, ${ }^{1}$ Ilka Molitor, ${ }^{1}$ Ulrike Schäfer, ${ }^{1} \dagger$ \\ Norbert Speich, ${ }^{1} \neq$ Robert Huber, ${ }^{2}$ Rainer Deutzmann ${ }^{3}$ \\ and Hans G. Trüper ${ }^{1}$
}

Author for correspondence: Hans G. Trüper. Tel: +49228732320 . Fax: +49228737576.

e-mail: Trueper@uni-bonn.de

1 Institut für Mikrobiologie \& Biotechnologie, Rheinische FriedrichWilhelms-Universität Bonn, 53115 Bonn, Germany

2,3 Lehrstuhl für Mikrobiologie $^{2}$ and Institut für Biochemie 3 , Universitătsstr. 31, 93053 Regensburg, Germany
A sulfite-reductase-type protein was purified from the hyperthermophilic crenarchaeote Pyrobaculum islandicum grown chemoorganoheterotrophically with thiosulfate as terminal electron acceptor. In common with dissimilatory sulfite reductases the protein has an $\alpha_{2} \beta_{2}$ structure and contains high-spin sirohaem, non-haem iron and acid-labile sulfide. The oxidized protein exhibits absorption maxima at 280, 392, 578 and $710 \mathrm{~nm}$ with shoulders at 430 and $610 \mathrm{~nm}$. The isoelectric point of pH 8.4 sets the protein apart from all dissimilatory sulfite reductases characterized thus far. The genes for the $\alpha$ - and $\beta$-subunits (dsrA and dsrB) are contiguous in the order dsrAdsrB and most probably comprise an operon with the directly following dsrG and dsrC genes. dsrG and dsrC encode products which are homologous to eukaryotic glutathione $S$-transferases and the proposed $\gamma$-subunit of Desulfovibrio vulgaris sulfite reductase, respectively. dsrA and dsrB encode $44.2 \mathrm{kDa}$ and 41.2 kDa peptides which show significant similarity to the two homologous subunits DsrA and DsrB of dissimilatory sulfite reductases. Phylogenetic analyses indicate a common protogenotic origin of the $P$. islandicum protein and the dissimilatory sulfite reductases from sulfate-reducing and sulfideoxidizing prokaryotes. However, the protein from $P$. islandicum and the sulfite reductases from sulfate-reducers and from sulfur-oxidizers most probably evolved into three independent lineages prior to divergence of archaea and bacteria.

Keywords: Pyrobaculum islandicum, hyperthermophilic archaeon, dissimilatory sirohaem sulfite reductase, nucleotide sequence, evolution

\section{INTRODUCTION}

Since the discovery of dissimilatory sulfur reduction in Desulfuromonas acetoxidans (Pfennig \& Biebl, 1976) many sulfur-respiring prokaryotes have been described, most of which are hyperthermophilic archaea (Widdel, 1988; Stetter et al., 1990; Adams, 1990; Fauque et al., 1991; Schauder \& Kröger, 1993). Some of these sulfur respirers are able to use sulfite or thiosulfate as

†Present address: Forschungszentrum Jülich $\mathrm{GmbH}$, Institut für Biotechnologie, Postfach 1913, 52425 Jülich, Germany.

‡Present address : Laboratorium Dr Jung GmbH, Paul-Schallück Straße 8 , 50939 Köln, Germany.

The GenBank accession number for the sequence reported in this paper is U75249. additional electron acceptors (Widdel \& Hansen, 1992; Schauder \& Kröger, 1993). The hyperthermophilic crenarchaeote Pyrobaculum islandicum, an organism with an optimum growth temperature of $100^{\circ} \mathrm{C}$ which was isolated from an Icelandic geothermal power plant (Huber et al., 1987), is a representative of this group. Elemental sulfur is essential as electron acceptor for chemolithotrophic growth of this organism on $\mathrm{H}_{2}$; however, during organotrophic growth $P$. islandicum is also able to grow on sulfite, thiosulfate, cystine and oxidized glutathione as hydrogen acceptors. $P$. islandicum is not able to reduce sulfate.

While a reasonable number of studies have focused on the metabolism of elemental sulfur in archaea (Ma et al., 1993; Kletzin, 1994; Pedroni et al., 1995; Ma \& Adams, 
1994) the enzymes catalysing the reduction of thiosulfate and sulfite in these organisms have hardly been studied. Sulfite reductase from the dissimilatory sulfate reducer Archaeoglobus fulgidus is the only enzyme involved in sulfite reduction that has so far been characterized from an archaeon (Dahl et al., 1993).

Sulfite reductase (EC 1.8.99.1) catalyses the sixelectron reduction of sulfite to sulfide and is present in all organisms capable of reducing sulfite during anaerobic respiration investigated thus far (Fauque et al., 1991; Dahl et al., 1993). In addition, sulfite reductases with a proposed function in sulfide oxidation have been demonstrated for Thiobacillus denitrificans RT and Chromatium vinosum strain D (Schedel \& Trüper, 1979; Schedel et al., 1979; Hipp et al., 1997). Although several types of dissimilatory sulfite reductases can be differentiated on the basis of their spectral and redox properties, all of these enzymes share common characteristics: they consist of two different polypeptides in an $\alpha_{2} \beta_{2}$ structure and contain sirohaem, nonhaem iron and acid-labile sulfide (Peck \& Lissolo, 1988; LeGall \& Fauque, 1988; Fauque et al., 1991). In addition, the two primary sequences available from dissimilatory sulfate reducers (Dahl et al., 1993; Karkhoff-Schweizer et al., 1995) and the amino acid sequence of the sulfite reductase from C. vinosum show remarkable similarity, which led to the proposal that these enzymes have a common protogenotic ancestor (Hipp et al., 1997).

In this study we intended to clarify whether a protein similar to sirohaem sulfite reductase is present in thiosulfate- and sulfite-reducing prokaryotes not capable of sulfate reduction. We chose P. islandicum as an example because detection of the protein in this organism and sequencing of the respective genes allowed us to extend comparative analyses and phylogenetic considerations to a sulfite reductase of crenarchaeal origin.

\section{METHODS}

Bacterial strains, plasmids and media. $P$. islandicum (DSM $4184^{\mathrm{T}}$ ) was grown with $4 \mathrm{mM}$ sodium thiosulfate as electron acceptor as described by Huber et al. (1987). Mass cultures for enzyme production were grown in 300 litre enamel-protected fermenters which were gassed with $\mathrm{N}_{2}$. At $96^{\circ} \mathrm{C}$, the organisms were allowed to grow for $88 \mathrm{~h}$, harvested and stored as packed deep-frozen cells. Escherichia coli XL1-Blue (endA1 supE44 bsdR17 thi relA1 recA1 gyrA46 lac $\mathrm{F}^{\prime}\left[\right.$ proAB ${ }^{+}$ lacl ${ }^{\mathrm{a}}$ lacZ $\Delta \mathrm{M} 15 \operatorname{Tn} 10\left(\right.$ tet $\left.\left.^{\mathrm{r}}\right)\right]$ was the host for $\lambda$ ZAP II (Stratagene) and pBluescript plasmid derivatives. E. coli $\mathrm{DH} 5 \alpha$ [supE44 $\Delta$ lacU169 ( $\phi 80 \mathrm{~d} l a c Z \Delta M 15)$ hsdR17 recA1 endA1 gyrA96 thi-1 relA1] and E. coli NM522 [supE thi $\Delta$ (lac-proAB) hsd5 $\mathrm{F}^{\prime}$ (proAB lacl $^{\mathrm{a}}$ lacZ $\left.\left.\Delta \mathrm{M} 15\right)\right]$ were the hosts for pUC18 (Yanisch-Perron et al., 1985) derivatives and exonuclease-IIIgenerated plasmids, respectively. E. coli strains were grown in LB medium (Sambrook et al., 1989) or in double-strength YT medium (Miller, 1972). The media were supplemented with $12.5 \mu \mathrm{g}$ tetracycline $\mathrm{ml}^{-1}$ for E. coli XL1-Blue and with $100 \mu \mathrm{g}$ ampicillin $\mathrm{ml}^{-1}$ for plasmid-containing derivatives. Lambda phage derivatives were plated in top agar consisting of NZCYM (Sambrook et al., 1989) containing 0.7\% agarose.
X-Gal and IPTG were included in solid media to identify recombinant phage and plasmids containing inserts in the $\alpha$ portion of lac Z.

Assays and spectroscopic measurements. During purification procedures the sulfite-reductase-type protein from $P$. islandicum was followed by measuring the absorbances at 394 and $578 \mathrm{~nm}$ and the enrichment was monitored by the $A_{280} / A_{578}$ ratio. Concentrations of the protein are based on a molecular mass of $170800 \mathrm{Da}$, which was calculated from the deduced amino acid sequences of the $\alpha$ - and $\beta$-subunits and the $\alpha_{2} \beta_{2}$ structure of the enzyme. Protein determinations were done according to the method of Lowry using BSA as a standard. Non-haem iron content was determined by the method of Massey (1957). Acid-labile sulfide was determined according to King \& Morris (1966). Sirohaem content was measured by the method of Siegel et al. (1978).

Protein purification. Unless otherwise noted all purification steps were performed aerobically at room temperature in $20 \mathrm{mM}$ Tris/ $\mathrm{HCl}, \mathrm{pH}$ 9.5. Packed cells were taken up in about three times their volume of standard buffer, and disrupted by ultrasonic treatment (Schöller disintegrator, $1 \mathrm{~min} \mathrm{ml}^{-1}$ for $20 \mathrm{~s}$ intervals at $4{ }^{\circ} \mathrm{C}$ with maximum power). The broken cell mass was then centrifuged at $25000 \mathrm{~g}$ for $30 \mathrm{~min}$ to remove larger fragments. Ammonium sulfate was added to the supernantant of a subsequent centrifugation at $140000 \mathrm{~g}$ to $40 \%$ saturation at $0{ }^{\circ} \mathrm{C}$. The precipitated protein was separated from the supernatant by centrifugation $(25000 \mathrm{~g}$, $30 \mathrm{~min}$ ) and discarded. The supernatant was applied to a Pharmacia-FPLC system and was separated on a Phenylsepharose CL-4B FastFlow (low-substituted) column (volume $90 \mathrm{ml}, \mathrm{XK26} / 60$ column) equilibrated with $40 \%$ ammonium sulfate in standard buffer. Using a linear decreasing gradient from $40 \%$ to $0 \%$ ammonium sulfate $(700 \mathrm{ml})$ the sulfitereductase-type protein eluted between $5 \%$ and $0 \%$ ammonium sulfate. The combined fractions containing the enzyme had a purity index of $22 \cdot 2\left(A_{280} / A_{578}\right)$ and were dialysed against standard buffer with $150 \mathrm{mM} \mathrm{NaCl}$ after concentration by ultrafiltration using Amicon XM 50 or YM 30 filters. The protein solution was subjected to gel filtration on a HiLoad 16/60 Superdex 200 column equilibrated with standard buffer containing $150 \mathrm{mM} \mathrm{NaCl}$ at a flow rate of $0.2 \mathrm{ml} \mathrm{min}{ }^{-1}$. The combined fractions (purity index 13.4) containing the protein were dialysed against start buffer ( $25 \mathrm{mM}$ Tris/acetate, $\mathrm{pH} \mathrm{8.8),} \mathrm{and} \mathrm{portions} \mathrm{of} \mathrm{less} \mathrm{than} 10 \mathrm{mg}$ total protein were further purified by chromatofocusing on Mono P HR 5/20, equilibrated with the same buffer. After washing the column with several volumes of start buffer to elute non-binding proteins, a $\mathrm{pH}$ gradient from $\mathrm{pH} 8.5$ to $\mathrm{pH} 7.5$ was applied using Pharmalyte and Polybuffer 96 (Pharmacia) as indicated by the supplier. The green protein was recovered at $\mathrm{pH} 8.4$ and separated from the ampholytes via gel filtration on Superose 6 equilibrated with standard buffer containing $150 \mathrm{mM} \mathrm{NaCl}$. Approximately $3 \mathrm{mg}$ electrophoretically homogeneous protein with a purity coefficient of 6.8 were obtained per $10 \mathrm{~g}$ cells.

Chemical and immunological characterizations of the protein. Non-denaturing PAGE was carried out with a cathodic buffer system (Reisfeld et al., 1962). The molecular mass of the native enzyme was estimated by running gels with varying acrylamide concentrations after Hedrick \& Smith (1968) and analysed by gel filtration on Superose 6 equilibrated with standard buffer containing $150 \mathrm{mM} \mathrm{NaCl}$. The proteins of the Boehringer Combithek II (no. 104558) were used as references. SDS-PAGE was carried out as described by Laemmli (1970). For immunoblots, the polypeptides were transferred from polyacrylamide gels to nitrocellulose membranes (Towbin et 
al., 1979) using a Bio-Rad semi-dry cell. The blots were blocked with $5 \%$ skim milk and incubated with antiserum against $A$. fulgidus sulfite reductase induced in rabbits (Dahl et al., 1993). Binding of the primary antibody was detected with horseradish-peroxidase-conjugated secondary antibody and immunoblot staining with 3',3-diaminobenzidine after Sambrook et al. (1989). Protein sequencing was done as described previously (Dahl et al., 1993). The isoelectric point of sulfite reductase was determined by analytical isoelectric focusing on Servalyt Precotes 3-10 using protein mixture 9 from Serva for calibration of the $\mathrm{pH}$ gradient.

Recombinant DNA methods. General methods were those described by Sambrook et al. (1989) and Ausubel et al. (1996). Unsheared genomic DNA of $P$. islandicum was obtained according to the protocol for A. fulgidus (Dahl et al., 1993). Exonuclease deletion clones were prepared using the nested deletion kit from Pharmacia. Sequencing was done on both strands by the dideoxy chain-termination method (Sanger et al., 1977) with both universal and de novo-synthesized primers using either the silver sequencing kit of Promega or Taq DNA polymerase and dye-labelled dideoxynucleotides. Dye-labelled DNA was analysed with a 373A DNA Sequencer from Applied Biosystems.

For DNA amplification by PCR, 25 pmol of each primer, 200 ng chromosomal template DNA, 2 U Taq DNA polymerase (Appligene), $5 \mu \mathrm{l}$ Taq DNA polymerase buffer (100 mM Tris/ $\mathrm{HCl}, \mathrm{pH} 9 \cdot 0,500 \mathrm{mM} \mathrm{KCl}, 15 \mathrm{mM} \mathrm{MgCl}_{2}, 1 \%$ Triton X-100, $2.0 \mathrm{mg}$ BSA or gelatin) and $0.2 \mathrm{mM}$ of each deoxynucleotide triphosphate were combined in a final reaction volume of $50 \mu \mathrm{l}$. After an initial denaturation step at $95^{\circ} \mathrm{C}$ for $5 \mathrm{~min}$, amplifications were carried out for 35 cycles, with each cycle consisting of $30 \mathrm{~s}$ at the appropriate annealing temperature, $30-90 \mathrm{~s}$ at $72{ }^{\circ} \mathrm{C}$ depending on the length of the product and $30 \mathrm{~s}$ at $95^{\circ} \mathrm{C}$, followed by annealing for $30 \mathrm{~s}$ and incubation at $72{ }^{\circ} \mathrm{C}$ for $5 \mathrm{~min}$. DNA probes for Southern blot experiments and screening of libraries were digoxigeninlabelled and colony hybridizations were performed following the protocol of Boehringer. PCR products were purified by gel electrophoresis and electroelution prior to cloning and hybridization steps. Southern and plaque hybridizations were performed overnight at $68^{\circ} \mathrm{C}$ as described previously (Dahl et al., 1994).

Cloning strategy. N-terminal peptide sequences for both the $\alpha$ - and the $\beta$-subunit of the sulfite-reductase-type protein could not be obtained, suggesting that they are blocked. Five tryptic peptides for a total of 49 residues and three tryptic peptides for a total of 38 residues were sequenced from the $\alpha$ - and $\beta$ subunits, respectively. Since the localization of the tryptic peptides within one subunit was not known, four sets of degenerate oligonucleotides were derived from the two chemically sequenced tryptic peptides of the $\alpha$-subunit FIGTWK and WFVGYL covering the two possible orientations. The four oligonucleotide mixtures were used as primers for PCR in the two possible combinations with genomic $P$. islandicum DNA as the template. A $300 \mathrm{bp} \mathrm{PCR} \mathrm{product} \mathrm{was}$ cloned in the pGEM-T vector (Promega) and sequenced. The derived amino acid sequence showed $33 \%$ identity to amino acids 235-331 of the $\alpha$-subunit of sulfite reductase from $A$. fulgidus. The $300 \mathrm{bp}$ amplicon was used as a probe to screen a $\lambda$ ZAP II library of $5 \cdot 5-7.5 \mathrm{~kb}$ BglII fragments of $P$. islandicum DNA. This library was constructed by digestion of $P$. islandicum DNA with BglII, filling in the restriction sites with the Klenow fragment of $E$. coli DNA polymerase and blunt-end ligation of the DNA to a NotI/EcoRI adapter. Sizefractionated fragments of $5 \cdot 5-7 \cdot 5 \mathrm{~kb}$ were ligated into $\lambda$ ZAP II, which had been digested with EcoRI and dephosphorylated.
pBluescript derivatives were prepared from $\lambda$ ZAP II by using the R408 single-stranded helper phage according to the protocol provided by Stratagene. Each of the ten positive clones analysed was found to contain the same $6.5 \mathrm{~kb}$ insert. Restriction enzyme and Southern hybridization analyses located the $300 \mathrm{bp}$ fragment on a central $1 \mathrm{~kb}$ HindIII/BstXI fragment flanked by 2 and $3 \mathrm{~kb}$ DNA portions of the insert. A $3229 \mathrm{bp}$ portion of the cloned BglII fragment was sequenced on both strands using a combination of subcloning via restriction enzyme or exonuclease III digestion and primer walking. The sequence data indicated the presence of a truncated ORF with homology to $d s r C$ from Desulfovibrio vulgaris (Karkhoff-Schweizer et al., 1993) at the 3' end of the sequenced DNA. A 225 bp PCR amplicon spanning bases 3003-3328 of the sequenced DNA fragment was used as a probe to identify several positive clones with a $1.5 \mathrm{~kb}$ HindIII/EcoRV insert containing the gene in full in a library of 1.2-1.7 kb HindIII/EcoRV fragments in the pUC18 vector.

\section{RESULTS}

\section{Purification and physico-chemical characterization of a sirohaem-sulfite-reductase-type protein from $P$. islandicum}

In all prokaryotes tested so far, growth on thiosulfate as terminal electron acceptor requires the presence of an enzyme which reductively cleaves thiosulfate to sulfite and sulfide and the presence of a dissimilatory sirohaem sulfite reductase which catalyses the six-electron reduction of sulfite to sulfide (LeGall \& Fauque, 1988; Fauque et al., 1991). Likewise, extracts of thiosulfategrown $P$. islandicum exhibited UV-visible spectra indicative of the presence of a sirohaem-containing protein. Purification from the soluble fraction led to a green, electrophoretically homogeneous protein with an absorption spectrum similar to those obtained for dissimilatory sirohaem sulfite reductases. The protein was shown to constitute $0.8 \%$ of the total cellular soluble protein. The relative molecular mass was found to be $170 \mathrm{kDa}$ by gel filtration and $165 \mathrm{kDa}$ by electrophoresis in polyacrylamide gels after Hedrick \& Smith (1968). SDS-PAGE analysis revealed that the protein consists of two different subunits of 42 and $40 \mathrm{kDa}$. Our results indicate that the native protein is a tetramer with a quaternary structure of $\alpha_{2} \beta_{2}$. The isoelectric point was determined to be at $\mathrm{pH} 8.4$ by analytical isoelectric focusing.

The oxidized protein exhibited absorption maxima at 281,394 and $578 \mathrm{~nm}$ with a weak and a marked shoulder at 430 and $610 \mathrm{~nm}$, respectively (Fig. 1). Furthermore, highly concentrated protein solutions showed a marked band around $710 \mathrm{~nm}$, indicating the presence of highspin sirohaem (Stolzenberg et al., 1981), a feature shared by all dissimilatory sulfite reductases investigated thus far (LeGall \& Fauque, 1988; Fauque et al., 1991). The enzyme was not reducible with dithionite at room temperature. The molar extinction coefficients of the purified $P$. islandicum protein at 281, 394 and $578 \mathrm{~nm}$ were estimated to be 366,175 and $52 \mathrm{mM}^{-1} \mathrm{~cm}^{-1}$, respectively.

Upon extraction with acetone hydrochloride (Siegel et al., 1978) the haem prosthetic group of the enzyme 


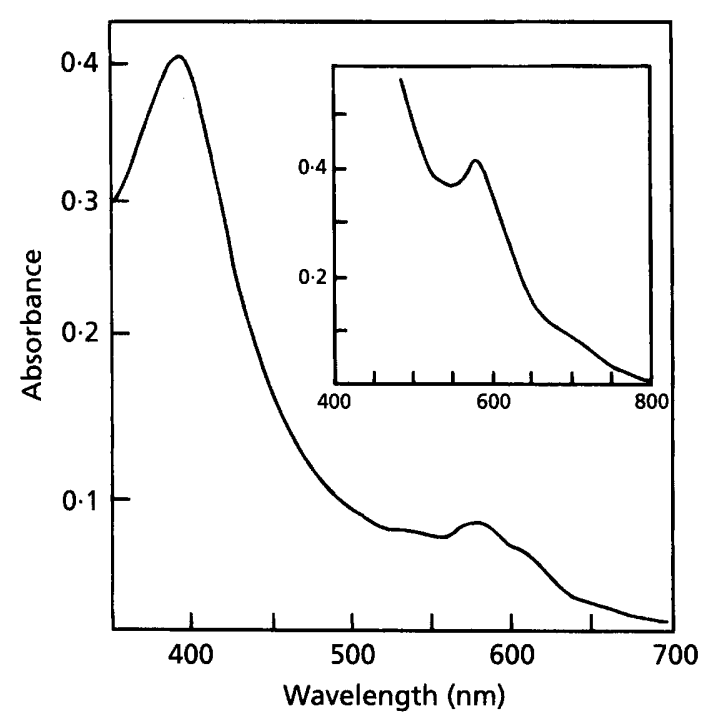

Fig. 1. Absorption spectrum of oxidized sulfite-reductase-type protein from $P$. islandicum. The spectrum of a $2 \cdot 1 \mu \mathrm{M}$ protein solution in $20 \mathrm{mM}$ Tris $/ \mathrm{HCl}, \mathrm{pH} 9.5$, was recorded under nitrogen at room temperature. Inset, $9.8 \mu \mathrm{M}$ protein solution.

exhibited absorption peaks at 594 and $365 \mathrm{~nm}$, similar to sirohaem preparations obtained from sulfite reductases (Siegel et al., 1978; Fauque et al., 1991; Dahl et al., 1993). After transfer to pyridine the resulting pyridine haemochrome yielded a spectrum with maxima at 557 and $399 \mathrm{~nm}$ typical for metalled sirohaem (Siegel et al., 1978; Murphy et al., 1974). The intensity of the spectrum corresponded to approximately two sirohaem groups per $\alpha_{2} \beta_{2}$ unit. This result is confirmed by the extinction coefficient at the Soret peak, which is very close to that of dissimilatory sulfite reductase from A. fulgidus. This enzyme has also been reported to contain two sirohaem groups per molecule (Dahl et al., 1993). An analysis for acid-labile sulfide gave a value of $24 \mathrm{~mol}$ sulfide per mol of enzyme. Iron determinations gave a value of 22 nonhaem $\mathrm{Fe}$ atoms per enzyme molecule.

The molecular mass and quaternary structure, as well as the presence of sirohaem, iron and acid-labile sulfide and the absorption spectrum with a Soret peak centred around $390 \mathrm{~nm}$ classify the protein purified from $P$. islandicum as a dissimilatory sulfite reductase (Table 1). However, the protein does not exactly resemble any of the sulfite reductases characterized so far. The spectrum lacks the pronounced absorption peak at $628 \mathrm{~nm}$ and the split Soret peak present in desulfoviridin (Lee \& Peck, 1971) as well as the maximum absorption at $545 \mathrm{~nm}$ shown by desulforubidin (Lee et al., 1973b; Arendsen et al., 1993). The C. vinosum, T. denitrificans and A. fulgidus enzymes have maxima at 595, 594 and $592 \mathrm{~nm}$, respectively, instead of $578 \mathrm{~nm}$ (Schedel et al., 1979; Schedel \& Trüper, 1979; Dahl et al., 1993). The UV-visible spectrum of the P. islandicum enzyme most closely resembles that of P582 from the spore-forming

Table 1. Comparison of the $P$. islandicum sirohaem-sulfite-reductase-type protein with dissimilatory sulfite reductases from other organisms

References: 1, Dahl et al. (1993); 2, Hatchikian \& Zeikus (1983); 3, Lee et al. (1973a); 4, Karkhoff-Schweizer et al. (1995); 5, Wolfe et al. (1994); 6, Pierik et al. (1992); 7, Schedel et al. (1979); 8, Hipp et al. (1997).

\begin{tabular}{|c|c|c|c|c|c|}
\hline Property & $\begin{array}{l}\text { Pyrobaculum } \\
\text { islandicum }\end{array}$ & $\begin{array}{l}\text { Archaeoglobus } \\
\text { fulgidus }\end{array}$ & $\begin{array}{c}\text { Thermodesulfobacterium } \\
\text { commune } \\
\text { (desulfofuscidin) }\end{array}$ & $\begin{array}{c}\text { Desulfovibrio } \\
\text { vulgaris } \text { s.,5,6 }^{3,4,6} \\
\text { (desulfoviridin) }\end{array}$ & $\begin{array}{c}\text { Chromatium } \\
\text { vinosum }^{7,8}\end{array}$ \\
\hline $\begin{array}{l}\text { Absorption maxima }(\mathrm{nm}) \text {, } \\
\varepsilon\left(\mathrm{mM}^{-1} \mathrm{~cm}^{-1}\right)\end{array}$ & $\begin{array}{l}394,175 \\
578,52\end{array}$ & $\begin{array}{l}394,184 \\
593,60\end{array}$ & $\begin{array}{l}389,310 \\
576,89\end{array}$ & $\begin{array}{l}390, \mathrm{NG} \\
408,150 \\
580, \mathrm{NG} \\
628,50\end{array}$ & $\begin{array}{l}392,302 \\
594,98\end{array}$ \\
\hline Molecular mass $(\mathrm{kDa})^{*}$ & 170 & 218 & 167 & 226 & 280 \\
\hline $\begin{array}{l}\text { Subunit composition } \\
\text { and molecular mass } \\
(\mathrm{kDa})\end{array}$ & $\begin{array}{l}2 \alpha(44 \cdot 2) \dagger \\
2 \beta(41 \cdot 2) \dagger\end{array}$ & $\begin{array}{l}2 \alpha(47 \cdot 4) \dagger \\
2 \beta(41 \cdot 7) \dagger\end{array}$ & $\begin{array}{l}2 \alpha(47) \\
2 \beta(47)\end{array}$ & $\begin{array}{l}2 \alpha(49 \cdot 1) \\
2 \beta(42 \cdot 5) \\
2 \gamma(11 \cdot 9) ?\end{array}$ & $\begin{array}{l}4 ? \alpha(46 \cdot 8) \dagger \\
4 ? \beta(40 \cdot 0) \dagger\end{array}$ \\
\hline Non-haem iron $\ddagger$ & 22 & $22-24$ & $20-21$ & $10-22 \$$ & 51 \\
\hline Acid-labile sulfur $\ddagger$ & 24 & 20 & $16-17$ & $10-22$ & 47 \\
\hline Sirohaem $\neq$ & $2 \cdot 1$ & 2 & 4 & 2 & NG \\
\hline Isoelectric point $(\mathrm{pH})$ & $8 \cdot 4$ & $4 \cdot 2$ & $<7$ & $4 \cdot 3-4 \cdot 5$ & NG \\
\hline
\end{tabular}

NG, Not given.

*Determined by gel filtration or equilibrium sedimentation.

† Deduced from nucleotide sequence.

‡Atoms or groups per $\alpha_{2} \beta_{2}$-structured enzyme molecule $\left(\alpha_{4} \beta_{4}\right.$-structured in the case of C. vinosum).

$\$$ Total iron. 


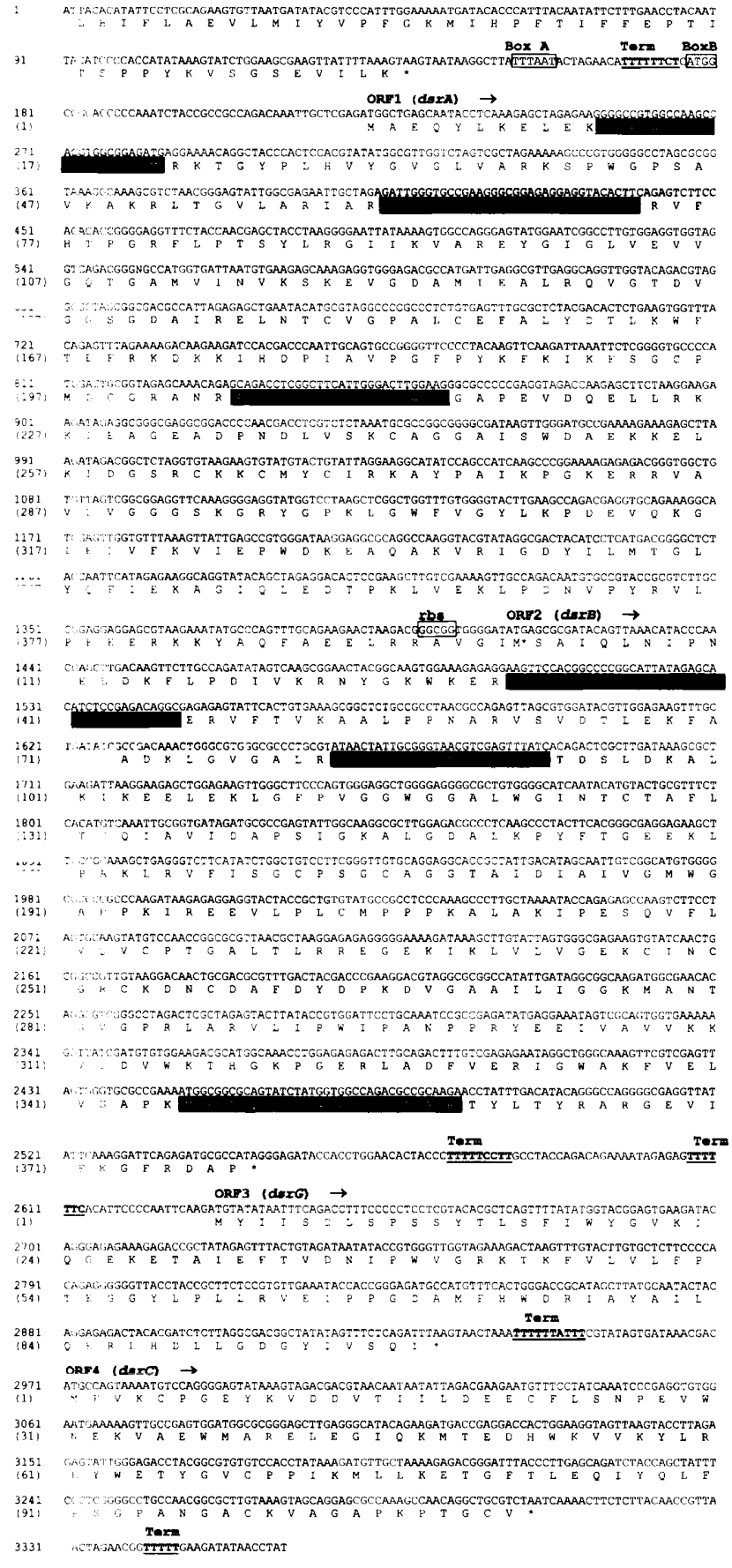

Fig. 2. Nucleotide sequence of the $P$. islandicum $d s r$ locus. Deduced amino acid sequences of four ORFs, designated $d s r A$, $d s r B, d s r G$ and $d s r C$, are shown under the sequence. Nucleotides are numbered and amino acid positions are shown in parentheses. The following features are indicated: sequences that conform to the 'Box $A$ ' and 'Box $B$ ' consensus motifs for promoters in methanogenic archaea; Term, putative transcription termination signals; rbs, putative ribosomebinding site. Amino acid residues shown on a black background correspond to tryptic peptide sequences that were chemically determined from the purified $\alpha$-and $\beta$-subunits.
Gram-positive sulfate reducer Desulfotomaculum nigrificans. However, like all other dissimilatory sulfite reductases characterized thus far, this enzyme has an isoelectric point in the acidic $\mathrm{pH}$ range since it readily binds to DEAE-cellulose at $\mathrm{pH} 8.04$ (Trudinger, 1970) and thereby differs substantially from the $P$. islandicum protein with its isoelectric point of $\mathrm{pH} \mathrm{8.4}$. The $P$. islandicum protein isolated in this study therefore is distinct from all dissimilatory sulfite reductases characterized thus far.

\section{Nucleotide sequence analysis}

The genes for the sulfite-reductase-type protein from $P$. islandicum were cloned as described in Methods. A total of $3360 \mathrm{bp}$ were sequenced on both strands and four ORFs of 1194, 1137, 303 and 336 bp were identified (Fig. 2). The upstream ORF1 encodes a 397 residue, $44 \cdot 2 \mathrm{kDa}$ peptide which contains sequences identical to all those chemically determined for the $\alpha$-subunit. ORF2 encodes a 378 residue, $41.2 \mathrm{kDa}$ peptide containing 38 amino acids corresponding to those found in three chemically sequenced tryptic peptides of the $\beta$-subunit. We concluded that ORF1 and ORF2 are the genes for the $\alpha$ - and $\beta$-subunits, respectively.

The molecular masses deduced for the ORF1- and ORF2-encoded peptides are in good agreement with the values obtained for the $\alpha$ - and $\beta$-subunits by SDS-PAGE analysis. A molecular mass of 170800 was calculated for the native $\alpha_{2} \beta_{2}$-structured protein, which is close to the value obtained by gel filtration. The calculated isoelectric points for the ORF1- and ORF2-encoded pep-

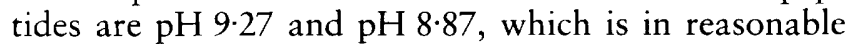
accordance with the isoelectric point of $\mathrm{pH} 8.4$ determined for the native protein by analytical isoelectric focusing.

Experimental data indicate that the structural elements of constitutive archaeal promoters can be recognized in the $\mathrm{T} / \mathrm{C}_{\mathrm{TTA}}{ }^{\mathrm{T}} /{ }_{\mathrm{A}} \mathrm{A}$ ('box A') sequence (Dalgaard \& Garrett, 1993). A box A motif was found centred $66 \mathrm{nt}$ upstream from $d s r A$ (boxed in Fig. 1). The box A motif is usually centred approximately $26 \mathrm{nt}$ from the transcription initiation site, which in many, but not all, archaea is the $G$ within the conserved sequence ${ }^{\mathrm{A}} / \mathrm{T}_{\mathrm{T}} \mathrm{TG}^{\mathrm{A}} / \mathrm{C}$ ('box B') (Hain et al., 1992). Such a potential start site is located 25 bases downstream of the centre of the proposed box A element. While ORF1 and ORF2 are closely linked with overlapping stop and start codons, ORF2/ORF3 and ORF3/ORF4 are separated by 82 and $37 \mathrm{nt}$, respectively. In these intergenic regions poly $(\mathrm{T})$ stretches are found. Comparable to the situation in other archaea (Dalgaard \& Garrett, 1993) these poly(T) stretches could function as transcription terminators. We nevertheless assume that ORF1-ORF4 comprise a single transcriptional unit since promoter-like sequences could not be identified upstream of ORF3 and ORF4 and termination of archaeal transcripts has been proposed to be relatively ineffective with extensive readthrough occurring between genes (Dalgaard \& Garrett, 1993). 
As shown in Fig. 2, except for ORF2, possible ShineDalgarno sequences complementary to the $3^{\prime}$ terminus of archaeal 16S rRNA (UCCUCC ...; Brown et al., 1989) could not be identified at an appropriate distance from the ATG start codons of the sequenced $P$. islandicum genes. As many transcripts from hyperthermophilic archaea lack such sequence stretches it has been suggested that factors other than a Shine-Dalgarno sequence are important for ribosomal interaction (Dalgaard and Garrett, 1993).

The entire sequenced DNA fragment has a $G+C$ content of $50.4 \mathrm{~mol} \%$, which is slightly higher than the value of $46 \%$ found for $P$. islandicum total DNA (Huber et al., 1987). In common with many other archaeal genes (Brown et al., 1989; Tiboni et al., 1993; Pedroni et al., 1995 ; Dahl et al., 1993; Speich et al., 1994), P. islandicum shows a marked preference for AGG and AGA among the arginine codons. The observed strong preference for $C$ in codons of the type NNC/T may favour efficient translation (Cram et al., 1987). As previously observed in other members of the Archaea (Cue et al., 1985; Reeve et al., 1986), the dinucleotide CG is under-represented in coding regions.

\section{Peptides encoded by $d s r A$ and $d s r B$}

BLAST (Altschul et al., 1990) and FASTA (Devereux et al., 1984) searches with the amino acid sequences of ORF1 and ORF 2 indicated strong similarities with the $\alpha$ - and $\beta$ subunits of the dissimilatory sirohaem sulfite reductases from A. fulgidus, D. vulgaris and C. vinosum (Dahl et al., 1993; Hipp et al., 1997). As reported for the sulfite reductase genes from the latter three organisms (Dahl et al., 1993; Karkhoff-Schweizer et al., 1995; Hipp et al., 1997), ORF1 and ORF2 are homologous to each other and probably arose by gene duplication. Weak similarities to other sirohaem-containing proteins (assimilatory sulfite reductase and nitrite reductase) were also found. According to the nomenclature for dissimilatory sulfite reductase genes we named the respective $P$. islandicum ORFs $d s r A$ and $d s r B$. Sulfite reductase genes have also tentatively been identified in the course of a genome sequencing project on Pyrobaculum aerophilum (Fitz-Gibbon et al., 1997) which is closely related to $P$. islandicum, but in contrast to the latter organism is facultatively aerobic (Völkl et al., 1993). The sequence data are, however, neither complete nor have they yet been deposited in GenBank and are therefore not available for comparative analysis.

Both DsrA and DsrB contain sequences conforming to the homology regions $\mathrm{H} 1-\mathrm{H} 4$ (Fig. 3) which are conserved between the symmetry-related halves of the haemoprotein of E. coli assimilatory sirohaem sulfite reductase and among other sirohaem-containing sulfite and nitrite reductases (Crane et al., 1995). Crane et al. (1995) showed that key residues important for stability and function of sirohaem proteins are clustered in these homology regions. Homology regions $\mathrm{H} 2$ and $\mathrm{H} 3$ each contain a pair of strictly conserved cysteine residues in the arrangements Cys- $\mathrm{X}_{5}$-Cys and Cys- $\mathrm{X}_{3}$-Cys, respect-

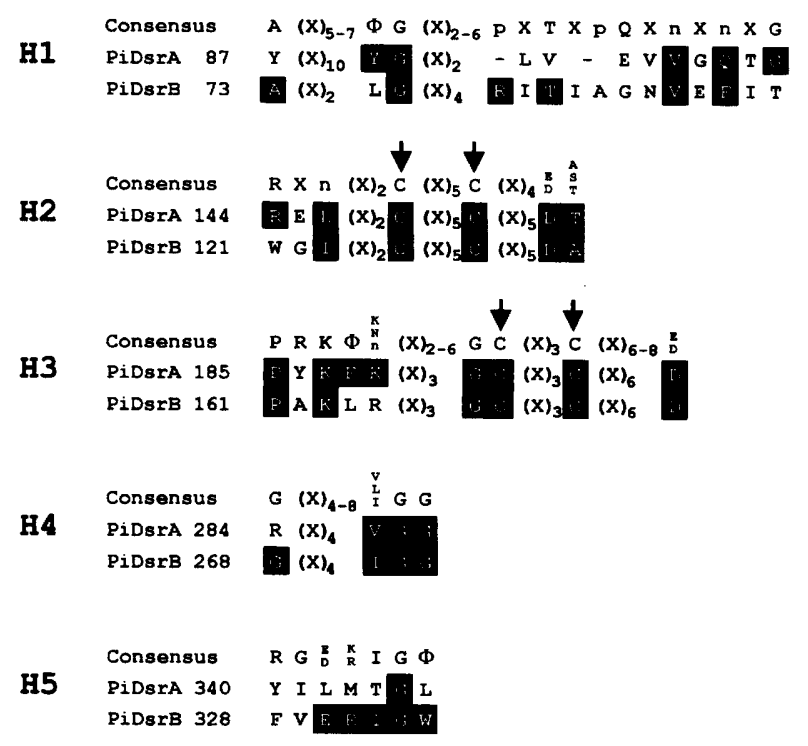

Fig. 3. Alignment of the deduced amino acid sequences of dsrA and $d s r B$ with the consensus sequences for the five homology regions $\mathrm{H} 1-\mathrm{H} 5$ proposed to be conserved in sirohaem sulfite and nitrite reductases (Crane et al., 1995). Amino acids matching the consensus are shown on a black background. Cysteine residues conforming to the four cysteines of the 'cys-motif' sequence Cys- $X_{5}-$ Cys- $X_{n}-$ Cys- $X_{3}-$ Cys (Campbell \& Kinghorn, 1990), which theoretically have the potential to ligate a sirohaem-associated $\left[\mathrm{Fe}_{4} \mathrm{~S}_{4}\right]$ cluster (Ostrowski et al., 1989; Crane et al., 1995) are marked by arrows. Amino acid positions are indicated. PiDsrA and PiDsrB, P. islandicum dsrAand $d s r B$-encoded peptides; $n$, non-polar residue; $p$, polar residue; $\Phi$, aromatic residue.

ively. In the E. coli enzyme these four cysteine residues co-ordinate the binding of an $\left[\mathrm{Fe}_{4} \mathrm{~S}_{4}\right]$ cluster and one of them also functions as a bridging ligand to the sirohaem prosthetic group (Ostrowski et al., 1989; Crane et al., 1995). Similar to the situation in A. fulgidus sulfite reductase (Crane et al., 1995), the $\alpha$-subunit of the $P$. islandicum protein does not contain a sequence matching homology region $\mathrm{H} 5$ whereas such a sequence is present in DsrB (Fig. 3).

Dissimilatory sulfite reductases are the only sirohaemcontaining proteins characterized thus far that contain amino acid sequences typical for the binding of additional $\left[\mathrm{Fe}_{4} \mathrm{~S}_{4}\right]$ clusters in both subunits (Dahl et al., 1993; Karkhoff-Schweizer et al., 1995; Hipp et al., 1997). $d s r A$ and $d s r B$ from $P$. islandicum also encode the typical sequence Cys- $\mathrm{X}_{2}-$ Cys- $\mathrm{X}_{2}-$ Cys- $\mathrm{X}_{3}$-Cys (George et al., 1985), which is located at exactly the same position as in the subunits of the dissimilatory sulfite reductases, namely just beyond the second group of the sirohaem- $\left[\mathrm{Fe}_{4} \mathrm{~S}_{4}\right]$-binding cysteines.

\section{The ORF3 (dsrG)-encoded protein}

ORF3 encodes a $100 \mathrm{aa}, 11.5 \mathrm{kDa}$ peptide with a theoretical isoelectric point of $\mathrm{pH} 4.94$ and an aliphatic index of $110 \cdot 1$. Upon FASTA and BLAST searches the ORF3-encoded protein revealed weak but significant 
PiDsrG 1

sj28 1

1GSQ 1

PiDsrg 56

Sj28 50

1GSQ 47
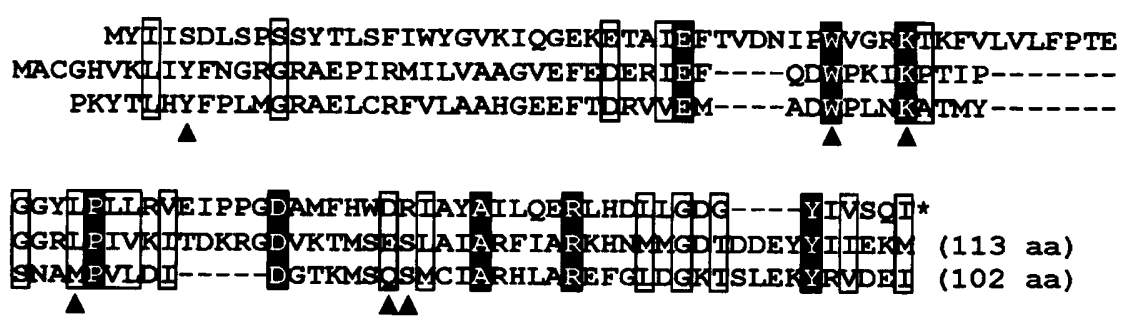

Fig. 4. Alignment of the $d s r G$-encoded polypeptide (PiDsrG) with the $\mathrm{N}$-terminal halves of the glutathione S-transferases from Schistosoma japonicum (Sj28; Henkle et al., 1990; GenBank number U58012) and from squid digestive gland (1GSQ; Tomarev et al., 1993; Ji et al., 1995; GenBank number L02052). Residues proposed to form electrostatic interactions with glutathione in Mu and Sigma class glutathione S-transferases are marked by triangles (Ji et al., 1995). Similar amino acid residues in all three sequences are boxed, identical amino acid residues are shown on a black background. For this comparison, the following are considered similar: aspartate, glutamate, asparagine and glutamine $(D, E, N$ and $Q)$; arginine, histidine and lysine $(\mathrm{R}, \mathrm{H}$ and $\mathrm{K})$; isoleucine, valine, methionine and leucine $(\mathrm{I}, \mathrm{V}, \mathrm{M}$ and $\mathrm{L})$; phenylalanine, tyrosine and tryptophane $(F, Y$ and $W)$; serine, threonine, proline, alanine and glycine $(S, T, P, A$ and $G)$ (Dayhoff et al., 1978).

\section{PiDsrC \\ DvDsvC \\ HaeYccK \\ ECYCCK}

PiDsrC

DvDsvC

HaeYcck

EcYccK
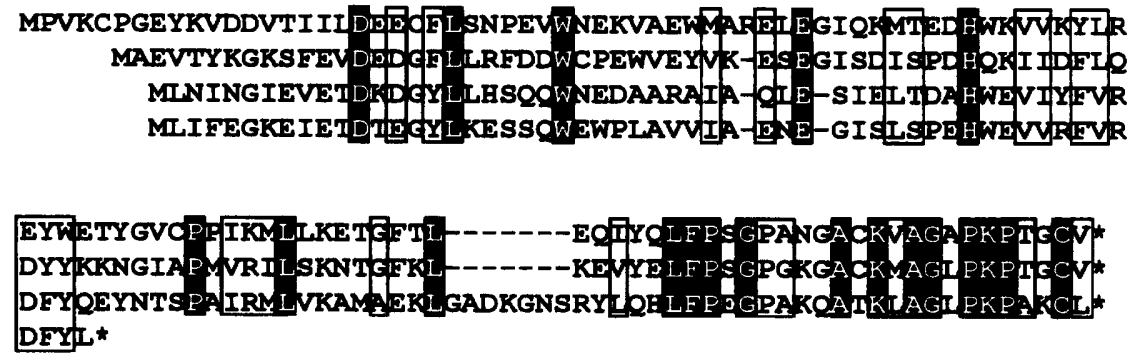

Fig. 5. Alignment of the dsrC-encoded polypeptide (PiDsrC) with DsvC from D. vulgaris (DvDsvC; Karkhoff-Schweizer et al., 1993) and the yccK-encoded polypeptides from $E$. coli (EcYccK; GenBank number P45572) and $H$. influenzae (HaeYccK; GenBank number U32763). Boxes and amino acid similarity groups are as in Fig. 4.

similarity to domain I of glutathione $S$-transferases, especially to the enzymes from trematodes of the genus Schistosoma (Henkle et al., 1990). We therefore chose the name $d s r G$ for ORF3. Crystallographic analyses revealed that most interactions between glutathione $S$ transferase and glutathione occur within domain I, which is therefore considered to constitute the glutathione-binding site (Ji et al., 1992, 1995; Sinning et al., 1993). Of the amino acid residues identified to have direct polar contact with glutathione (Ji et al., 1995), two are strictly conserved in $P$. islandicum DsrG and M50L as well as Q62D (numbering refers to 1GSQ from squid digestive gland, Ji et al., 1995) are conservative changes (Fig. 4). However, the otherwise strictly conserved tyrosine residue at the $\mathrm{N}$-terminus of all glutathione $S$-transferase sequences (Ji et al., 1995) is not present in the $d s r G$-encoded protein. Tyrosine to phenylalanine or equivalent mutations reduce glutathione $S$-transferase activity almost completely but do not significantly impair the protein's ability to bind glutathione, which implicates a function of this residue in catalysis rather than in glutathione binding (Dirr et al., 1994). The highly conserved proline residue (P52 in 1GSQ) which is also present in glutaredoxin is essential for a correct backbone conformation at the glutathionebinding site. Residue D96 (in 1GSQ) which is not present in DsrG has also been proposed to play a role in glutathione binding. However, Widersten et al. (1992) suggested, on the basis of studies with a D96N mutant, that this residue does not significantly contribute to the binding of glutathione. Regarding the rather low similarity of DsrG to glutathione $S$-transferases, it seems premature to speculate about the function of this hypothetical polypeptide in $P$. islandicum. It is, however, interesting to note in this respect that $P$. islandicum is able to grow on oxidized glutathione as electron acceptor during organoheterotrophic growth (Huber et al., 1987).

\section{The ORF4 (dsrC)-encoded protein}

ORF4 encodes a 111 residue, $12.7 \mathrm{kDa}$ polypeptide with a theoretical isoelectric point of $\mathrm{pH} 4.88$ and an aliphatic index of $77 \cdot 21$. A homology search identified a significant degree of sequence identity with the $d s r C$ gene product of D. vulgaris (Karkhoff-Schweizer et al., 1993) and the products of the potential $y c c K$ genes from E. coli and Haemophilus influenzae (Fig. 5). The $d s r C$-encoded polypeptide has been proposed to constitute a subunit of dissimilatory sulfite reductase from $D$. vulgaris (Pierik et al., 1992). 


\section{DISCUSSION}

A sirohaem- $\left[\mathrm{Fe}_{4} \mathrm{~S}_{4}\right]$ containing-protein which exhibits features specific for dissimilatory sulfite reductases was purified and characterized from the extremely thermophilic archaeon $P$. islandicum. Furthermore, we cloned and sequenced $d s r A$ and $d s r B$, the genes encoding the $\alpha$ and $\beta$-subunits of this protein.

Dissimilatory sulfite reductases are usually assayed with reduced methylviologen as electron donor (Widdel \& Hansen, 1992). One way to obtain reduced methylviologen is reduction with hydrogen via hydrogenase, thereby allowing the sulfite reductase reaction to be followed manometrically. As enzymes from the hyperthermophile $P$. islandicum have temperature optima close to $100^{\circ} \mathrm{C}$, the optimum growth temperature of the organism, and a pure, hyperthermophilic hydrogenase was not available, this assay was impracticable. In the case of the hyperthermophilic sulfite reductase from $A$. fulgidus this problem was circumvented by using electrochemically reduced methylviologen and the enzyme could be proven in crude extracts at $85^{\circ} \mathrm{C}$ by following the decrease in absorbance at $600 \mathrm{~nm}$ (Dahl et al., 1993). However, at $100^{\circ} \mathrm{C}$ chemical reoxidation of the dye was so rapid that sulfite reductase activity could not be attributed to the protein from $P$. islandicum purified in this work with absolute certainty.

Nevertheless, several lines of evidence suggest that this protein works as a dissimilatory sulfite reductase in $P$. islandicum. (i) The high concentration of the protein in thiosulfate-grown cells $(0.8 \%$ of the total cellular soluble protein) indicates a dissimilatory function and is in the same range as found for dissimilatory sirohaem sulfite reductases in sulfate-reducing prokaryotes (Peck \& LeGall, 1982; Dahl et al., 1993). (ii) The protein exhibits several characteristics which, to the best of our knowledge, occur exclusively in dissimilatory sulfite reductases: a molecular mass in the range of $200 \mathrm{kDa}$, an $\alpha_{2} \beta_{2}$-subunit composition, the presence of two sirohaem groups in the high-spin state per holoenzyme, and the presence of 22 non-haem iron atoms and 24 atoms of acid-labile sulfide per holoenzyme, which allow the formation of six $\left[\mathrm{Fe}_{4} \mathrm{~S}_{4}\right]$ clusters. (iii) Crude extracts of $P$. islandicum and purified protein cross-react with antiserum raised against $A$. fulgidus sulfite reductase (data not shown). (iii) The amino acid sequences of the $\alpha$ - and $\beta$-subunits of the P. islandicum protein show homology to the respective subunits of dissimilatory sulfite reductases over their entire length. All essential cluster-binding residues are conserved. (iv) Besides sulfite reductases, sirohaem as a prosthetic group has only been described in ammonia-forming assimilatory nitrite reductases. All sirohaem nitrite reductases characterized thus far differ substantially from the $P$. islandicum protein and dissimilatory sulfite reductases with respect to molecular mass, subunit composition, and content of prosthetic groups (Siegel et al., 1987; Romero et al., 1987; Back et al., 1988; Kinghorn \& Campbell, 1989; Peakman et al., 1990; Brittain et al., 1992; Lin et al., 1993). The fact that assimilatory nitrite reductases are usually repressed in the presence of ammonia (Cole, 1988) and the sulfite-reductase-type protein from $P$. islandicum was isolated from cells grown with ammonia as nitrogen source further argues against a function of this enzyme in nitrite reduction. Some sulfate-reducing bacteria can reduce nitrate and contain ammonia-producing nitrite reductases. These enzymes are, however, hexahaem cytochromes (Liu \& Peck, 1981). P. islandicum is furthermore not able to use nitrate as electron acceptor (Völkl et al., 1993).

It has been suggested that dissimilatory sulfite reductases may be membrane-associated in vivo because the generation of a protonmotive force by sulfate or sulfite reduction requires the transfer of reducing power from the membrane-localized electron transport chain to sulfite reductase (Drake \& Akagi, 1977). In agreement with this suggestion, Steuber et al. (1994) reported the purification of a dissimilatory sulfite reductase from the membrane fraction of Desulfovibrio desulfuricans. In contrast, treatment of $P$. islandicum membrane fractions with the detergents SDS, Triton X-114 and CHAPS did not lead to the solubilization of any sirohaem-containing proteins. In this context it may be important to note that after ultracentrifugation Steuber et al. (1994) separated whole cells and membrane fractions used to isolate the 'membrane-bound' enzyme only on the basis of a different colour. If whole cells remained in the membrane fraction an extraction with Triton X-100 as applied might well have disrupted these cells. Soluble sulfite reductase present in these cells could then have mimicked the presence of a membrane-bound enzyme. As has been found for all dissimilatory sulfite reductases sequenced so far, hydropathy analyses (Kyte \& Doolittle, 1982) of DsrA and DsrB from P. islandicum did not reveal markedly hydrophobic segments that would be likely to mediate membrane integration. Rossi et al. (1993) proposed that the components of a potential transmembrane redox complex transfer electrons from periplasmic hydrogenase to the soluble cytoplasmic enzymes of sulfate reduction in D. vulgaris. A comparable protein complex may donate electrons to the soluble sulfite reductase of $P$. islandicum; it must, however, be borne in mind that the presence of elemental sulfur as electron acceptor is essential for chemoautotrophic growth of the organism on hydrogen (Huber et al., 1987).

Both the $P$. islandicum $d s r A$ and $d s r B$ genes encode all four cysteine residues required for sirohaem- $\left[\mathrm{Fe}_{4} \mathrm{~S}_{4}\right]$ binding (Ostrowski et al., 1989; Crane et al., 1995), which suggests the presence of a total of four sirohaem- $\left[\mathrm{Fe}_{4} \mathrm{~S}_{4}\right]$ groups in the $\alpha_{2} \beta_{2}$-structured holoprotein. However, quantitative measurements unambiguously showed the presence of only two mol sirohaem per mol of holoprotein. With the exception of desulfofuscidin from Thermodesulfobacterium species (Hatchikian \& Zeikus, 1983; Fauque et al., 1990), all dissimilatory-type sulfite reductases have also been reported to contain only two sirohaem units per $\alpha_{2} \beta_{2}$ molecule (LeGall \& Fauque, 1988; Dahl et al., 1993; Arendsen et al., 1993). For the dissimilatory sulfite 
reductases sequenced so far the presence of only two sirohaem groups has been explained by the mutation, in the $\beta$-subunit, of one of the $\left[\mathrm{Fe}_{4} \mathrm{~S}_{4}\right]$ cysteine cluster ligands to a threonine (Dahl et al., 1993). It now seems clear from our results with the $P$. islandicum protein that the presence of all potential cluster-binding cysteine residues cannot be the only prerequisite for sirohaem$\left[\mathrm{Fe}_{4} \mathrm{~S}_{4}\right]$ binding. In this respect the crystal structure of the $E$. coli assimilatory sulfite reductase haemoprotein (Crane et al., 1995) is very instructive. This protein is proposed to have arisen by fusion of two homologous proteins similar to DsrA and DsrB. Both halves of the assimilatory enzyme fold into similar structures, particularly in the regions that bind the cofactors, suggesting an ancestral homodimer with a sirohaem and an $\left[\mathrm{Fe}_{4} \mathrm{~S}_{4}\right]$ group on each subunit. Subsequently, the protein evolved so that the DsrA-like C-terminal portion of the contemporary protein contains the cysteines that ligate the $\left[\mathrm{Fe}_{4} \mathrm{~S}_{4}\right]$ cluster which is exchange-coupled to the sirohaem group and the DsrB-like $\mathrm{N}$-terminal half contributes most of the residues that bind the sirohaem carboxyl groups. These two parts are joined by a linker region which contributes a short stretch of amino acids that acts as a structural mimic for ligand-bound sirohaem and associates with those C-terminal residues homologous to the sirohaem-carboxylate-binding residues in the N-terminal half of the protein (Crane et al., 1995; Crane \& Getzoff, 1996). This stretch of amino acid residues is conserved in the $\beta$ - but not in the $\alpha$ subunits of dissimilatory sulfite reductases, and accordingly is found only in DsrB from P. islandicum (Fig. 3 , homology region $\mathrm{H} 5$ ). If this region indeed forms a structural mimic for sirohaem and occupies the sirohaem-binding site on DsrA only one sirohaem $\left[\mathrm{Fe}_{4} \mathrm{~S}_{4}\right]$ group would be expected per $\alpha \beta$ dimer irrespective of how many potential cluster-ligating cysteines are present in DsrB. In support of this view, Crane \& Getzoff (1996) pointed out that it is unlikely that in dissimilatory sulfite reductases one subunit alone can bind both the sirohaem and the $\left[\mathrm{Fe}_{4} \mathrm{~S}_{4}\right]$ cluster and maintain the covalent association of the cofactors indicated by electronic exchange coupling observed between the cofactors.

The chemically determined content of iron and acidlabile sulfide indicates that the sulfite-reductase-type protein from $P$. islandicum contains six $\left[\mathrm{Fe}_{4} \mathrm{~S}_{4}\right]$ clusters per $\alpha_{2} \beta_{2}$ molecule. The presence of $\left[\mathrm{Fe}_{4} \mathrm{~S}_{4}\right]$ centres in the protein is supported by the occurrence of amino acid sequences characteristic for $\left[\mathrm{Fe}_{4} \mathrm{~S}_{4}\right]$-ferredoxins. Similar to the situation in $A$. fulgidus, two of the $\left[\mathrm{Fe}_{4} \mathrm{~S}_{4}\right]$ cores are probably present as sirohaem- $\left[\mathrm{Fe}_{4} \mathrm{~S}_{4}\right]$ clusters, while the other four would be bound by the ferredoxin-like sequences in the $\alpha$ - and $\beta$-subunits.

The fact that a gene homologous to $d s \nu \mathrm{C}$, the gene for the proposed $11 \mathrm{kDa} \gamma$-subunit of $D$. vulgaris sulfite reductase (Pierik et al., 1992), is found downstream of $d s r A B$ in $P$. islandicum was rather unexpected as comparable to results obtained for the A. fulgidus sulfite reductase (Dahl et al., 1993) - SDS-PAGE analyses of the protein purified from $P$. islandicum on high-per- centage acrylamide gels clearly showed that it does not contain a third subunit. In D. vulgaris, the $d s v C$ gene is neither linked to nor co-ordinately expressed with those for the $\alpha$ - and $\beta$-subunits of sulfite reductase (KarkhoffSchweizer et al., 1993). In addition, the observation of Steuber et al. (1995) that an $11 \mathrm{kDa}$ polypeptide appears to be only loosely associated to $D$. desulfuricans sulfite reductase and is lost in part during purification leads us to doubt that an $11 \mathrm{kDa}$ polypeptide is indeed an integral part of dissimilatory sulfite reductases. However, the observed association of the polypeptide with some sulfite reductases (Pierik et al., 1992; Wolfe et al., 1994; Arendsen et al., 1993), together with the close linkage of the $d s r A B$ and $d s r C$ genes in $P$. islandicum indicate an important though as yet unknown function of DsrC in sulfite reduction. The presence of a gene homologous to $d s r C$ in E. coli and H. influenzae, organisms which do not contain dissimilatory sulfite reductases but can synthesize assimilatory sirohaem sulfite and nitrite reductases under appropriate growth conditions, may hint at a function of the respective gene products in assembly, folding or stabilization of sirohaem proteins.

Dissimilatory sulfite reductases consist of relatively long polypeptide chains containing both semi-conserved and highly conserved regions, and occur in sulfate- and sulfite-reducing prokaryotes as well as in some sulfur oxidizers (Dahl et al., 1993; Karkhoff-Schweizer et al., 1995; Hipp et al., 1997). Therefore, the sulfite reductase subunits in principle appeared to be suited to trace the evolution of dissimilatory sulfur metabolism. Fig. 6 shows a bootstrap parsimony analysis of an amino acid alignment of the DsrA and DsrB sequences available so far. The tree exhibits a dyad symmetry, i.e. the DsrA and DsrB polypeptides are more closely related among themselves than to each other in one organism. When constant evolutionary rates are assumed this tree topology strongly suggests that the duplication of the common ancestor of the $d s r A B$ genes must have happened prior to entering the lineages leading to the contemporary sequences. The observed tree topology deviates from the phylogeny inferred from $16 \mathrm{~S}$ rRNAencoding genes which would have placed together the two proteobacteria C. vinosum and D. vulgaris on one hand and the two archaea $A$. fulgidus and P. islandicum on the other (Olsen \& Woese, 1994). Instead, the subunits of the $P$. islandicum protein are located on separate branches and the polypeptides from the sulfate reducers $D$. vulgaris and $A$. fulgidus are more closely related to each other than to those of the sulfideoxidizing C. vinosum. As discussed earlier for C. vinosum, D. vulgaris and A. fulgidus (Hipp et al., 1997), the most likely explanation for the observed tree topology is that the sequences compared in Fig. 6 stem from paralogous (Gogarten, 1994) protein families that evolved into independent lineages in a protogenotic (Benner \& Ellington, 1990) world, i.e. prior to divergence into Bacteria and Archaea. In addition to the family of sulfite reductases working in the reductive direction and that of the enzymes working in the oxidative direction (Hipp et al., 1997) we now postulate 


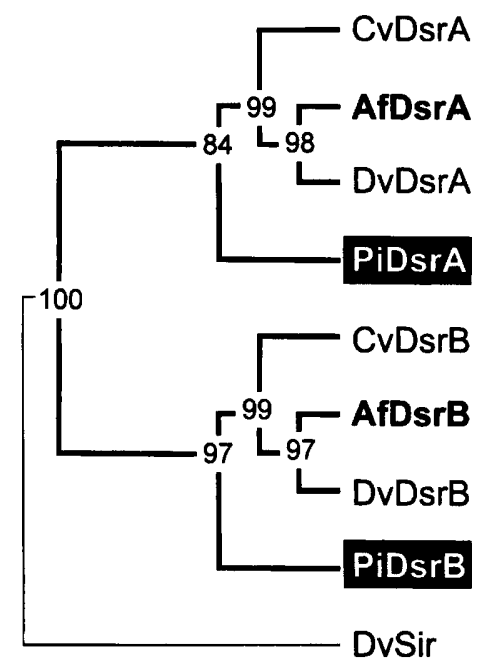

Fig. 6. Bootstrap parsimony analysis of amino acid alignments of DsrA and DsrB sequences with the sir gene product of $D$. vulgaris (Tan et al., 1991) as the outgroup. The unrooted tree was constructed by the program PROTPARS (Felsenstein, 1993) from an alignment produced with the program CLUSTAL $W$ (Higgins \& Sharp; 1989) using the Mutation Data Matrix (Dayhoff et al., 1978; George et al., 1990). The alignment comprised only the highly conserved part common to all sirohaem-binding enzymes. Only unambiguously aligned residues as estimated by statistically significant sequence similarities were included for the analyses; gaps in the data sets were avoided. Branch lengths are arbitrary. Numbers at the forks indicate the number of times the group consisting of the species which are to the right of that fork occurred among the trees out of 1000 bootstrap replications. The tree topology based on protein parsimony was verified by distance matrix analyses. Af, Archaeoglobus fulgidus; Cv, Chromatium vinosum, Dv, Desulfovibrio vulgaris; Pi, Pyrobaculum islandicum. Bold characters define archaea.

the existence of a third family of sulfite-reductase-typeproteins, the only currently known representative of which is the enzyme from the crenarchaeote $P$. islandicum. The protogenotic development of at least three different families of sulfite-reductase-type proteins points to an ancient evolutionary origin of the $d s r A B$ gene family, which is in accordance with the concept of Skyring \& Donnelly (1982) who claimed on the basis of geochemical data that the biochemical evolution of sulfite reduction occurred early on a primordial earth and even was the initial event leading to the evolution of dissimilatory sulfate reduction.

\section{ACKNOWLEDGEMENTS}

Support of this work by grant $\operatorname{Tr} 133 / 20$ from the Deutsche Forschungsgemeinschaft and by the Fonds der Chemischen Industrie is gratefully acknowledged. We thank Daniel C. Brune for helpful hints concerning the sirohaem content of the protein purified from $P$. islandicum, and Wolfgang M. Hipp as well as Michael Wagner for helpful discussions on the evolution of sulfite reductases.

\section{REFERENCES}

Adams, M. W. W. (1990). The metabolism of hydrogen by extremely thermophilic, sulfur-dependent bacteria. FEMS Microbiol Lett 75, 219-238.

Altschul, S. F., Gish, W., Miller, W., Myers, E. W. \& Lipman, D. J. (1990). Basic local alignment search tool. J Mol Biol 215, 403-410.

Arendsen, A. F., Verhagen, M. F. J. M., Wolbert, R. B. G., Pierik, A. J., Stams, A. J. M., Jetten, M. S. M. \& Hagen, W. R. (1993). The dissimilatory sulfite reductase from Desulfosarcina variabilis is a desulforubidin containing uncoupled metalated sirohemes and $\mathrm{S}=9 / 2$ iron-sulfur clusters. Biochemistry 32, 10323-10330.

Ausubel, F. A., Brent, R., Kingston, R. E., Moore, D. D., Seidman, J. G., Smith, J. A. \& Struhl, K. (1996). Current Protocols in Molecular Biology, New York: John Wiley.

Back, E., Burkhart, W., Moyer, M., Privalle, L. \& Rothstein, S. (1988). Isolation of cDNA clones coding for spinach nitrite reductase: complete sequence and nitrate induction. Mol Gen Genet 212, 20-26.

Benner, S. A. \& Ellington, A. D. (1990). 'Progenote' or 'protogenote'? Science 248, 943-944.

Brittain, T., Blackmore, R., Greenwood, C. \& Thomson, A. J. (1992). Bacterial nitrite-reducing enzymes. Eur J Biochem 209, 793-802.

Brown, J. W., Daniels, C. J. \& Reeve, J. N. (1989). Gene structure, organization, and expression in archaebacteria. Crit Rev Microbiol 16, 287-338.

Campbell, W. H. \& Kinghorn, J. R. (1990). Functional domains of assimilatory nitrate reductases and nitrite reductases. Trends Biochem Sci 15, 315-319.

Cole, J. A. (1988). Assimilatory and dissimilatory reduction of nitrate to ammonia. In The Nitrogen and Sulphur Cycles, pp. 281-329. Edited by J. A. Cole \& S. J. Ferguson. Cambridge: Cambridge University Press.

Cram, D. S., Sherf, B. A., Libby, R. T., Mattaliano, R. J., Ramachandran, K. L. \& Reeve, J. N. (1987). Structure and expression of the genes, $\operatorname{mcr} B D C G A$, which encode the subunits of component $\mathrm{C}$ of methyl coenzyme $\mathrm{M}$ reductase in Methanococcus vanniellii. Proc Natl Acad Sci USA 84, 3992-3996.

Crane, B. R. \& Getzoff, E. D. (1996). The relationship between structure and function for the sulfite reductases. Curr Opin Struct Biol 6, 744-756.

Crane, B. R., Siegel, L. M. \& Getzoff, E. D. (1995). Sulfite reductase structure at $1.6 \AA$ : evolution and catalysis for reduction of inorganic anions. Science 270, 59-67.

Cue, D., Beckler, G. S., Reeve, J. N. \& Konisky, J. (1985). Structure and sequence diversity of two archaebacterial genes. Proc Natl Acad Sci USA 82, 4207-4211.

Dahl, C. \& Truper, H. G. (1994). Enzymes of dissimilatory sulfide oxidation in phototrophic bacteria. Methods Enzymol 243, 400-421.

Dahl, C., Kredich, N. M., Deutzmann, R. \& Truper, H. G. (1993). Dissimilatory sulphite reductase from Archaeoglobus fulgidus: physico-chemical properties of the enzyme and cloning, sequencing and analysis of the reductase genes. $J$ Gen Microbiol $139,1817-1828$.

Dahl, C., Speich, N. \& Truper, H. G. (1994). Enzymology and molecular biology of sulfate reduction in the extremely thermophilic archaeon Archaeoglobus fulgidus. Methods Enzymol 243, 331-349.

Dalgaard, J. Z. \& Garrett, R. A. (1993). Archaeal hyperthermophile genes. In The Biochemistry of Archaea (Archaebacteria), pp. 
535-563. Edited by M. Kates, D. J. Kushner \& A. T. Matheson. Amsterdam: Elsevier.

Dayhoff, M. O., Schwartz, R. M. \& Orcutt, B. C. (1978). A model of evolutionary change in proteins. In Atlas of Protein Sequence and Structure, pp. 345-352. Edited by M. O. Dayhoff. Washington, DC: National Biochemical Research Foundation.

Devereux, J., Haeberli, P. \& Smithies, O. (1984). A comprehensive set of sequence analysis programs for the VAX. Nucleic Acids Res 12, 387-395.

Dirr, H., Reinemer, P. \& Huber, R. (1994). Refined crystal structure of porcine class Pi glutathione S-transferase (pGST P1-1) at $2 \cdot 1 \AA$ resolution. $J$ Mol Biol 243, 72-92.

Drake, H. L. \& Akagi, J. M. (1977). Bisulfite reductase of Desulfovibrio vulgaris: explanation for product formation. J Bacteriol 132, 139-143.

Fauque, G., Lino, A. R., Czechowski, M., Kang, L., DerVartanian, D. V., Moura, J. J. G., LeGall, J. \& Moura, I. (1990). Purification and characterization of bisulfite reductase (desulfofuscidin) from Desulfovibrio thermophilus and its complexes with exogenous ligands. Biochim Biophys Acta 1040, 112-118.

Fauque, G., LeGall, J. \& Barton, L. L. (1991). Sulfate-reducing and sulfur-reducing bacteria. In Variations in Autotrophic Life, pp. 271-337. Edited by J. M. Shively \& L. L. Barton. New York: Academic Press.

Felsenstein, J. (1993). PHYLIP (Phylogeny Inference Package) version 3.5c. ftp.bio.indiana.edu/molbio/evolve

Fitz-Gibbon, S., Choi, A. J., Miller, J. H., Stetter, K. O., Simon, M. I., Swanson, R. \& Kim, U.-J. (1997). A fosmid-based genomic map and identification of 474 genes of the hyperthermophilic archaeon Pyrobaculum aerophilum. Extremophilis 1, 36-51.

George, D. G., Hunt, L. T., Yeh, L.-S. \& Barker, W. C. (1985). New perspectives on bacterial ferredoxin evolution. J Mol Evol 22, 20-31.

George, D. G., Barker, W. C. \& Hunt, L. T. (1990). Mutation data matrix and its uses. Methods Enzymol 183, 333-351.

Gogarten, J. P. (1994). Which is the most conserved group of proteins? Homology-orthology, paralogy, xenology, and the fusion of independent lineages. $J$ Mol Evol 39, 541-543.

Hain, J., Reiter, W.-D., Hüdepohl, U. \& Zillig, W. (1992). Elements of an archaeal promoter defined by mutational analysis. Nucleic Acids Res 20, 5423-5428.

Hatchikian, E. C. \& Zeikus, J. G. (1983). Characterization of a new type of dissimilatory sulfite reductase present in Thermodesulfobacterium commune. J Bacteriol 153, 1211-1220.

Hedrick, J. L. \& Smith, A. J. (1968). Size and charge isomer separation and estimation of molecular weights of proteins by disc electrophoresis. Arch Biochem Biophys 126, 155-164.

Henkle, K. J., Davern, K. M., Wright, M. D., Ramos, A. J. \& Mitchell, G. F. (1990). Comparison of the cloned genes of the 26and 28-kilodalton glutathione-S-transferases of Schistosoma japonicum and Schistosoma mansoni. Mol Biochem Parasitol 40, 23-34.

Higgins, D. G. \& Sharp, P. M. (1989). Clustal: a package for performing multiple sequence alignment on a microcomputer. Gene 73, 237-244.

Hipp, W. M., Pott, A. S., Thum-Schmitz, N., Faath, I., Dahl, C. \& Truper, H. G. (1997). Towards the phylogeny of APS reductases and sirohaem sulfite reductases in sulfate-reducing and sulfuroxidizing prokaryotes. Microbiology 143, 2891-2902.

Huber, R., Kristjanson, J. K. \& Stetter, K. O. (1987). Pyrobaculum gen. nov., a new genus of neutrophilic, rod-shaped archaebacteria from continental solfataras growing optimally at $100^{\circ} \mathrm{C}$. Arch Microbiol 149, 95-101.

Ji, X., Zhang, P., Armstrong, R. N. \& Gilliland, G. L. (1992). The three-dimensional structure of a glutathione $S$-transferase from the mu gene class, structural analysis of the binary complex of isoenzyme 3-3 and glutathione at $2 \cdot 2-\AA$ resolution. Biochemistry 31, 10169-10184.

Ji, X., von Rosenvinge, E. C., Johnson, W. W., Tomarev, S. I., Piatigorsky, J., Armstrong, R. N. \& Gilliland, G. L. (1995). Threedimensional structure, catalytic properties, and evolution of a sigma class glutathione transferase from squid, a progenitor of the lens $S$-crystallins of cephalopods. Biochemistry 34, 5317-5328.

Karkhoff-Schweizer, R. R., Bruschi, M. \& Voordouw, G. (1993). Expression of the $\gamma$-subunit gene of desulfoviridin-type dissimilatory sulfite reductase and of the $\alpha$ - and $\beta$-subunit genes is not coordinately regulated. Eur J Biochem 211, 501-507.

Karkhoff-Schweizer, R. R., Huber, D. P. W. \& Voordouw, G. (1995). Conservation of the genes for dissimilatory sulfite reductase from Desulfovibrio vulgaris and Archaeoglobus fulgidus allows their detection by PCR. Appl Environ Microbiol 61, 290-296.

King, T. E. \& Morris, R. O. (1966). Determination of acid-labile sulfide and sulfhydryl groups. Methods Enzymol 10, 634-637.

Kinghorn, J. R. \& Campbell, E. I. (1989). Amino acid sequence relationships between bacterial, fungal, and plant nitrate and nitrite reductase proteins. In Molecular and Genetic Aspects of Nitrate Assimilation, pp. 385-403. Edited by J. L. Wray \& J. R. Kinghorn. Oxford: Oxford Science Publications.

Kletzin, A. (1994). Sulfur oxidation and reduction in archaea. Sulfur oxygenase/reductase and hydrogenases from the extremely thermophilic and facultatively anaerobic archaeon Desulfurolobus ambivalens. Syst Appl Microbiol 16, 534-543.

Kyte, J. \& Doolittle, R. F. (1982). A simple method for displaying the hydropathic character of a protein. $J$ Mol Biol 157, 105-132. Laemmli, U. K. (1970). Cleavage of structural proteins during the assembly of the head of bacteriophage T4. Nature 227, 680-685.

Lee, J.-P. \& Peck, H. D., Jr (1971). Purification of the enzyme reducing bisulfite to trithionate from Desulfovibrio gigas and its identification as desulfoviridin. Biochem Biophys Res Commun 45, 583-589.

Lee, J.-P., LeGall, J. \& Peck, H. D., Jr (1973a). Isolation of assimilatory- and dissimilatory-type sulfite reductases from Desulfovibrio vulgaris. J Bacteriol 115, 529-542.

Lee, J.-P., Yi, C.-S., LeGall, J. \& Peck, H. D., Jr (1973b). Isolation of a new pigment, desulforubidin, from Desulfovibrio desulfuricans (Norway strain) and its role in sulfite reduction. J Bacteriol 115, 453-455.

LeGall, J. \& Fauque, G. (1988). Dissimilatory reduction of sulfur compounds. In Biology of Anaerobic Microorganisms, pp. 587-639. Edited by A. J. B. Zehnder. New York: John Wiley.

Lin, J. T., Goldman, B. S. \& Stewart, V. (1993). Structures of genes nas $A$ and nas $B$, encoding assimilatory nitrate and nitrite reductases in Klebsiella pneumoniae M5al. J Bacteriol 175, 2370-2378.

Liu, M. C. \& Peck, H. D., Jr (1981). Isolation of a hexaheme cytochrome from Desulfovibrio desulfuricans and its identification as a new type of nitrite reductase. J Biol Chem 256, 13159-13164.

Ma, K. \& Adams, M. W. W. (1994). Sulfide dehydrogenase from the hyperthermophilic archaeon Pyrococcus furiosus: a new multifunctional enzyme involved in the reduction of elemental sulfur. J Bacteriol 176, 6509-6517.

Ma, K., Schicho, R. N., Kelly, R. M. \& Adams, M. W. (1993). 
Hydrogenase of the hyperthermophilic Pyrococcus furiosus is an elemental sulfur reductase or sulfhydrogenase: evidence for a sulfur-reducing hydrogenase ancestor. Proc Natl Acad Sci USA 90, 5341-5344.

Massey, V. (1957). Studies on succinic dehydrogenase. VII. Valency state of the iron in beef heart dehydrogenase. J Biol Chem 229, 763-770.

Miller, J. H. (1972). Experiments in Molecular Genetics, pp. 431-433. Cold Spring Harbor, NY: Cold Spring Harbor Laboratory.

Murphy, M. J., Siegel, L. M., Tove, S. R. \& Kamin, H. (1974). Siroheme: a new prosthetic group participating in six-electron reduction reactions catalyzed by both sulfite and nitrite reductases. Proc Natl Acad Sci USA 71, 612-616.

Olsen, J. \& Woese, C. R. (1994). The winds of (evolutionary) change: breathing new life into microbiology. J Bacteriol 176, $1-6$.

Ostrowski, J., Wu, J.-Y., Rueger, D. C., Miller, B. E., Siegel, L. M. \& Kredich, N. M. (1989). Characterization of the cysJIH regions of Salmonella typhimurium and Escherichia coli B.J Biol Chem 264, 15726-15737.

Peakman, T., Crouzet, J., Mayaux, J. F., Busby, S., Mohan, S., Harborne, N., Wootton, J., Nicolson, R. \& Cole, J. (1990). Nucleotide sequence, organisation and structural analysis of the products of genes in the nirB-cysG region of the Escherichia coli K12 chromosome. Eur J Biochem 191, 1864-1873.

Peck, H. D., Jr \& LeGall, J. (1982). Biochemistry of dissimilatory sulphate reduction. Philos Trans R Soc Lond Ser B Biol Sci 298, 443-466.

Peck, H. D., Jr \& Lissolo, T. (1988). Assimilatory and dissimilatory sulfate reduction: enzymology and bioenergetics. In The Nitrogen and Sulfur Cycles, pp. 99-132. Edited by J. A. Cole \& S. J. Ferguson. Cambridge: Cambridge University Press.

Pedroni, P., Della Volpe, A., Galli, G., Mura, G. M., Pratesi, C. \& Grandi, G. (1995). Characterization of the locus encoding the [Ni-Fe] sulfhydrogenase from the archaeon Pyrococcus furiosus: evidence for a relationship to bacterial sulfite reductases. Microbiology 141, 449-458.

Pfennig, N. \& Biebl, H. (1976). Desulfuromonas acetoxidans gen. nov. and sp. nov., a new anaerobic sulfur-reducing, acetateoxidizing bacterium. Arch Microbiol 110, 3-12.

Pierik, A. J., Duyvis, M. G., van Helvoort, J. M. L. M., Wolbert, R. B. G. \& Hagen, W. R. (1992). The third subunit of desulfoviridin-type dissimilatory sulfite reductases. Eur J Biochem 205, 111-115.

Reeve, J. N., Hamilton, P. T., Beckler, G. S., Morris, C. J. \& Clarke, C. H. (1986). Structure of methanogen genes. Syst Appl Microbiol 7, 5-10.

Reisfeld, R. A., Lewis, U. J. \& Williams, D. E. (1962). Disk electrophoresis of basic proteins and peptides on polyacrylamide gels. Nature 195, 281-283.

Romero, L. C., Galvan, F. \& Vega, J. M. (1987). Purification and properties of the siroheme-containing ferredoxin-nitrite reductase from Chlamydomonas reinhardtii. Biochim Biophys Acta 914, 55-63.

Rossi, M., Pollock, B. R., Reiji, M. W., Keon, R. G., Fu, R. \& Voordouw, G. (1993). The hmc operon of Desulfovibrio vulgaris subsp. vulgaris Hildenborough encodes a potential transmembrane redox protein complex. J Bacteriol 175, 4699-4711.

Sambrook, J., Fritsch, E. F. \& Maniatis, T. (1989). Molecular Cloning : a Laboratory Manual, 2nd edn. Cold Spring Harbor, NY: Cold Spring Harbor Laboratory.
Sanger, F., Nicklen, S. \& Coulson, A. R. (1977). DNA sequencing with chain-terminating inhibitors. Proc Natl Acad Sci USA 74, 5463-5467.

Schauder, R. \& Kröger, A. (1993). Bacterial sulphur respiration. Arch Microbiol 152, 423-497.

Schedel, M. \& Trüper, H. G. (1979). Purification of Thiobacillus denitrificans siroheme sulfite reductase and investigation of some molecular and catalytic properties. Biochim Biophys Acta 568, 454-467.

Schedel, M., Vanselow, M. \& Trüper, H. G. (1979). Siroheme sulfite reductase from Chromatium vinosum. Purification and investigation of some of its molecular and catalytic properties. Arch Microbiol 121, 29-36.

Siegel, L. M., Murphy, M. J. \& Kamin, H. (1978). Siroheme methods for isolation and characterization. Methods Enzymol 52, 436-447.

Siegel, L. M., Wilkerson, J. O. \& Janick, P. A. (1987). Structural studies on the siroheme [4Fe4S] cluster active center of spinach ferredoxin-nitrite reductase and Escherichia coli sulfite reductase. In Inorganic Nitrogen Metabolism, pp. 118-122. Edited by W. R. Ullrich, P. J. Aparacio, P. J. Syrett \& F. Castillo. New York: Springer.

Sinning, I., Kleyweg, G. J., Cowan, S. W. \& 10 other authors (1993). Structure determination and refinement of human alpha class glutathione transferase A1-1, and a comparison with the $\mathrm{Mu}$ and Pi class enzymes. $J$ Mol Biol 232, 192-212.

Skyring, G. W. \& Donnelly, T. H. (1982). Precambrian sulfur isotopes and a possible role for sulfite in the evolution of biological sulfate reduction. Precambrian Res 17, 41-61.

Speich, N., Dahl, C., Heisig, P., Klein, A., Lottspeich, F., Stetter, K. O. \& Trüper, H. G. (1994). Adenylylsulphate reductase from the sulphate-reducing archaeon Archaeoglobus fulgidus : cloning and characterization of the genes and comparison of the enzyme with other iron-sulphur flavoproteins. Microbiology 140, 1273-1284.

Stetter, K. O., Fiala, G., Huber, G., Huber, R. \& Segerer, A. (1990). Hyperthermophilic archaea. FEMS Microbiol Rev 75, 117-124.

Steuber, J., Cypionka, H. \& Kroneck, P. M. H. (1994). Mechanism of dissimilatory sulfite reduction by Desulfovibrio desulfuricans. Purification of a membrane-bound sulfite reductase and coupling with cytochrome $c_{3}$ and hydrogenase. Arch Microbiol 162, 255-260.

Steuber, J., Arendsen, A. F., Hagen, W. R. \& Kroneck, P. M. H. (1995). Molecular properties of the dissimilatory sulfite reductase from Desulfovibrio desulfuricans (Essex) and comparison with the enzyme from Desulfovibrio vulgaris (Hildenborough). Eur J Biochem 233, 873-879.

Stolzenberg, A. M., Strauss, S. H. \& Holm, R. H. (1981). Iron(II,III)chlorin and -isobacteriochlorin complexes. Models of the heme prosthetic groups in nitrite and sulfite reductases: means of formation and spectroscopic and redox properties. J Am Chem Soc 103, 4763-4778.

Tan, J., Helms, L. R., Swenson, R. P. \& Cowan, J. A. (1991). Primary structure of the assimilatory-type sulfite reductase from Desulfovibrio vulgaris (Hildenborough): cloning and nucleotide sequence of the reductase gene. Biochemistry 30, 9900-9907.

Tiboni, O., Cammarano, P. \& Sanangelantoni, A. M. (1993). Cloning and sequencing of the gene encoding glutamine synthetase I from the archaeum Pyrococcus woesei: anomalous phylogenies inferred from analysis of archaeal and bacterial glutamine synthetase I sequences. J Bacteriol 175, 2961-2969.

Tomarev, S. I., Zinovieva, R. D., Guo, K. \& Piatigorsky, J. (1993). Squid glutathione S-transferase. Relationships with other gluta- 
thione S-transferases and S-crystallins of cephalopods. $J$ Biol Chem 268, 4534-4542.

Towbin, H., Staehelin, T. \& Gordon, J. (1979). Electrophoretic transfer of proteins from polyacrylamide gels to nitrocellulose sheets: procedure and some applications. Proc Natl Acad Sci USA 76, 4350-4354.

Trudinger, P. A. (1970). Carbon monoxide-reacting pigment from Desulfotomaculum nigrificans and its possible relevance to sulfite reduction. J Bacteriol 104, 158-170.

Völkı, P., Huber, R., Drobner, E., Rachel, R., Burggraf, S., Trincone, A. \& Stetter, K. O. (1993). Pyrobaculum aerophilum sp. nov., a novel nitrate-reducing hyperthermophilic archaeum. Appl Environ Microbiol 59, 2918-2926.

Widdel, F. (1988). Microbiology and ecology of sulfate- and sulfur-reducing bacteria. In Biology of Anaerobic Microorganisms, pp. 469-585. Edited by J. B. Zehnder. New York: John Wiley.

Widdel, F. \& Hansen, T. A. (1992). The dissimilatory sulfate- and sulfur-reducing bacteria. In The Prokaryotes, 2nd edn., pp. 583-624. Edited by A. Balows, H. G. Trüper, M. Dworkin, W. Harder \& K.-H. Schleifer. New York: Springer.

Widersten, M., Kolm, R. H., Bjornestedt, R. \& Mannervik, B. (1992). Contribution of five amino acid residues in the glutathione binding site to the function of glutathione transferase P1-1. Biochem J 285, 377-381.

Wolfe, B. M., Lui, S. M. \& Cowan, J. A. (1994). Desulfoviridin, a multimeric-dissimilatory sulfite reductase from Desulfovibrio vulgaris (Hildenborough). Purification, characterization, kinetics and EPR studies. Eur J Biochem 223, 79-89.

Yanisch-Perron, C., Vieira, J. \& Messing, J. (1985). Improved M13 phage cloning vectors and host strains: nucleotide sequences of the M13mp18 and pUC19 vectors. Gene 33, 103-119.

Received 3 June 1997; revised 6 September 1997; accepted 19 September 1997. 